\title{
Responses to Drought Stress Levels of Strawberry Grown in Greenhouse Conditions
}

\author{
Berkant ÖDEMIŞ ${ }^{1}{ }^{\circledR}$, Derya KAZGÖZ CANDEMIR ${ }^{1}$ \\ Fatih EVRENDILEK ${ }^{2}$
}

\begin{abstract}
${ }^{1}$ Mustafa Kemal University, Agriculture Faculty, Biosystem Engineering Department, 31060, Hatay / Turkey 2 Bolu Abant İzzet Baysal University, Engineering Faculty, Environmental Engineering Department, 14030, Bolu / Turkey
\end{abstract}

\section{Article History}

Received 30 July 2020

Accepted 29 September 2020

First Online 10 October 2020

\section{Corresponding Author \\ E-mail: bodemisenator@gmail.com}

\author{
Keywords \\ Drought stress \\ Greenhouse \\ Strawberry \\ Vegetative parameters \\ Physiological parameters
}

\begin{abstract}
This experimental study was carried out using the 'Camarosa' cultivar strawberry plants grown in pots in greenhouse conditions. One control and two drought levels were created by bringing the existing soil water content of the pot to the field capacity (l $\left.\right|_{100}$-control) and using its 66\% (I66-mild drought

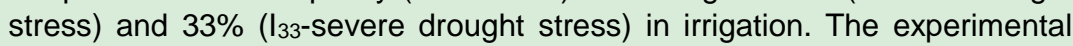
design of the randomized complete blocks design was applied in four replicates with 10 pots per replicate amounting to a total of 120 pots. In order to determine the plant response to the generated stress levels, stomatal conductivity (Sc, mmol $\mathrm{m}^{2} \mathrm{~s}^{-1}$ ), total chlorophyll content (SPAD, $\mu \mathrm{mol} \mathrm{m}^{-2} \mathrm{~s}^{-1}$ ), chlorophyll concentration (CC, $\mathrm{mg} \mathrm{g}^{-1}$ ), leaf surface temperature (LST, ${ }^{\circ} \mathrm{C}$ ), photosynthetic quantum yield (Qy, \%), photosynthetically active radiation (PAR, W m $\mathrm{m}^{-2}$ ), leaf water content (LWC, \%), yield $\left(\mathrm{g} \mathrm{pot}^{-1}\right)$, leaf area $\left(\mathrm{LA}, \mathrm{cm}^{2}\right)$, leaf number ( $\mathrm{LN})$, and crop water use (ET) were measured in three plants per each replicate. $1.89,3.62$, and $5.82 \mathrm{~L} \mathrm{pot}^{-1}$ were applied to $\mathrm{I}_{33}$, $\mathrm{I}_{66}$, and $\mathrm{I}_{100}$ as irrigation water, while 2.59, 3.92, and $5.59 \mathrm{~L} \mathrm{pot}^{-1}$ were crop water used from them, respectively. Average strawberry yield varied between 80 and $400 \mathrm{~g} \mathrm{pot}^{-1}$. The increased drought stress decreased Sc, SPAD, CC, Qy, PAR, LWC, LA, and LN but increased LST. All the measured variables had significant relationships with irrigation water and crop water use. Yield had a linear relationship with LST and LN and a polynomial relationship with Sc, SPAD, CC, Qy, PAR, LWC, and LA. Water and light use efficiencies were quantified and predicted through the best-fit (non-) linear models.
\end{abstract}

\section{Introduction}

The irregularity and extremity of precipitation regimes due to global climate change have caused droughts in many regions of the world and enhanced its severity in the semi-arid regions. Drought is one of the most important environmental stressors that limit plant growth and development. Plants protect themselves against drought stress by morphological, biochemical and physiological mechanisms by increasing their water use efficiency. The most important physiological properties include stomatal conductivity, leaf temperature (Jones, 1999), photosynthetic capacity (Lawlor and Cornic, 2002), phenological periods (Slafer et al., 2005; Richards, 2006), leaf area (Walter and Shurr, 2005), and chlorophyll content (Jackson et al., 1996).

The first physiological symptoms against drought stress occur in stomatal conductivity. The tendency of stomata in the leaves to close in the case of water scarcity in the root region reduces the gas exchange between the leaf intercellular void and the atmosphere (Kerepesi and Galiba, 2000). The reduction of $\mathrm{CO}_{2}$ use under a moderate drought stress usually relates to stoma closure (Mansfield 
and Davies, 1981). If the drought time is prolonged, the decrease in photosynthesis is not caused by stomatal closure, but from the membrane damage in mesophilic cells, the decreased chlorophyll content, and the deterioration in the transport and synthesis of assimilation products. The amount of decrease in photosynthesis relates to the severity and duration of drought stress, plant type, development period and leaf age, the oxidation of chloroplasts, and the structure of proteins and pigments (Passioura et al., 1993). The droughtresistant varieties accumulate more biomass (leaf area, number of leaves, amount of stem, and stem biomass) in their leaves than the drought-sensitive ones (Kerepesi and Galiba, 2000). Drought tolerance levels of plants are closely related to the timing of the stress that they are exposed to. If its severity and duration are not lethal, the physiological factors may be restored back to normal with the disappearance of the stress. For example, the vine tree when exposed to drought stress was found to have recovered by about $60 \%$ after one night, and fully in four days, if watered in terms of net $\mathrm{CO}_{2}$ assimilation rate $(\mathrm{A})$, and stomatal conductance (Sc) (Flexas et al., 2004). Some studies indicated that photosynthesis recovered within $24 \mathrm{~h}$ after irrigation (Flexas et al., 2004; Mittler et al., 2001) depending on the stress severity, and the crop varieties (Flexas et al., 2004). Strawberries need to be irrigated for their optimum growth and development in areas where the amount of precipitation is not sufficient although their genotypic differences may trigger different responses to drought. Klamkowski and Treder (2008) reported that although drought stress reduced the leaf area in all the cultivars, the weakening root development, and low yield were observed only in the varieties of Elkat, Ghaderi, and Siosemardeh. They stated that membrane stability index, net $\mathrm{CO}_{2}$ assimilation rate, stomatal conductance, transpiration rate, and chlorophyll content fell with the decreased soil water content. When exposed to drought stress, strawberry decreased its stomatal closure by rapidly increasing abscisic acid synthesis (ABA) at the roots (Blanke and Cooke, 2004). Thus, low transpiration rate may render strawberry drought-tolerant (Grant et al., 2010). The objective of this study was to determine the changes in crop water use, stomatal conductance (Sc), chlorophyll value (SPAD), photosynthetic quantum yield (Qy), photosynthetically active radiation (PAR), chlorophyll concentration, leaf surface temperature (LST), leaf water content (LWC), leaf area (LA), leaf number (LN), and yield in response to a changing drought stress level.

\section{Material and Method}

\subsection{Soil, plant and cultivation characteristics}

The research was carried out in an unheated plastic greenhouse with a dimension of $10.5 \times 22 \times$ $4 \mathrm{~m}$, with a side ventilation, in 2016.

Camarosa (Fragaria $x$ ananassa Duch.) strawberry cultivar was used as a tube seedling of four-weeks old with a minimum body thickness of $10 \mathrm{~mm}$. Pots used in growing had a diameter of $42 \mathrm{~cm}$, a length of $31 \mathrm{~cm}$, and a volume of $22 \mathrm{~L}$. Heavy potted soil brought from Amik Plain as a growing medium was first mixed with the sand brought from the stream bed and filled in pots with a total weight of $10 \mathrm{~kg}$. In order to enable drainage, seven holes in an equal diameter under the pots were drilled. Drainage water was collected in a container placed under a pot. Irrigation water of $\mathrm{C}_{1} \mathrm{~S}_{1}$ class was used. Soil salinity was determined as $0.19 \mathrm{dS} \mathrm{m}^{-1}$. And the blend ratio of soil to sand was $2 / 1$.

\subsection{Experimental design and applications}

The experiment was carried out in a total of 120 pots, with four repetitions, 10 pots in each repetition and one plant in each pot in response to three irrigation levels (IL) according to the experimental design of randomized complete blocks design. The three irrigation treatments were created by applying all the water required by a plant to reach the field capacity level (l 100 -control), and 66\% (I66-moderate drought) and $33 \%$ ( $\mathrm{I}_{33}$-severe drought) of the irrigation water required by the plant. The irrigation water amount to be given to the plants was determined by measuring the irrigation water amount required to bring them to the field capacity before weekly watering three pots next to the experimental pots. In determining the irrigation water amount before each irrigation, three pots were determined where irrigation water was applied with a specific beaker at certain intervals until water began to leak from underneath the pots. As soon as leakage was seen from underneath the pot, water application was stopped to determine the volume of water (in L). This amount determined corresponded to the full irrigation $\left(I_{100}\right)$, while $66 \%\left(I_{66}\right)$ and $33 \%$ (I $I_{33}$ of this amount were applied to the other pots by creating the two soil water contents, and thus, the two drought stress levels.

\subsection{Physiological measurements}

In order to determine the plant physiological responses to the water stress levels created, the physiological parameters (Sc, SPAD, LST, Qy, PAR) were measured before each irrigation prior to harvest so long as the leaf sizes were measurable: SPAD, Qy, PAR, Sc, LST, and PAR measurements were begun on the $26^{\text {th }}$ of February and repeated nine times during the experiments. LWC, LA, and $\mathrm{LN}$ measurements were made at the final harvest.

\subsubsection{Stomatal conductivity (Sc, $\left.\mathrm{mmol} \mathrm{m}^{2} \mathrm{~s}^{-1}\right)$}


Stomatal conductivity was measured one day before irrigation between 11:00 and 14:00 under clear sky. A leaf porometer with a portable desiccant (DECAGON SC-1) was used. Its calibration was realized with standard calibration papers before each measurement. The measurements were made on the $4^{\text {th }}, 5^{\text {th }}$, and $6^{\text {th }}$ pots in the middle of the repetitions marked for each replication.

\subsubsection{Total chlorophyll content (SPAD, $\mu \mathrm{mol} \mathrm{m}^{-}$ ${ }^{2} \mathrm{~s}^{-1}$ ) and chlorophyll concentration (CC, $\mathrm{mg} \mathrm{g}^{-1}$ )}

Total chlorophyll content is one of the best plant physiological signals under the stress conditions and was measured using a SPAD instrument (Minolta SPAD 502) based on the color change in the leaf. Measurements were taken as the average of four readings in three pots in each replication before each irrigation treatment and repeated nine times during the experiments. Chlorophyll concentration was determined analyzing total chlorophyll of young leaves that completed their development sampled near the harvest period, according to Arnon (1949). In the analysis, $0.1 \mathrm{~mL}$ of the leaf samples in porcelain mortar were homogenized by adding $1-2 \mathrm{~mL}$ of $80 \%$ acetone. The samples were filtered from a coarse filter paper into $10 \mathrm{~mL}$ glass tubes and completed with $80 \%$ acetone up to $10 \mathrm{~mL}$. The absorbance values obtained from the wavelength of $652 \mathrm{~nm}$ using a spectrophotometer (SP-3000 Plus Spectrophotometer) were substituted into Eq. (1) where the total chlorophyll concentration was determined (Lichtenhaler and Welburn, 1983).

$T C C=\frac{(A 652 \times 27.8) \times 10}{\text { Sample weight } \times 1000}$

\subsubsection{Leaf surface temperature $\left(L S T,{ }^{\circ} \mathrm{C}\right)$}

An infrared thermometer instrument (Spectrum Tech. Inc., IR Crop temperature meter) was used to measure LST as the average of four readings in the plants of three pots marked each time. Measurements were made one day before irrigation between 11:00-14:00 under the clear sky and repeated nine times during the experiments.

\subsubsection{Photosynthetic quantum yield (Qy, \%) and photosynthetically active radiation (PAR, $W^{-2}$ )}

Photosynthetic quantum yield and PAR were measured in the plants of three pots one day before irrigation between 11:00 and 14:00 under the clear sky using a portable FlourPen FP100 and repeated nine times during the experiments.

\subsection{Vegetative and generative measurements}

During the harvest period, the leaves of the plants in each replication at the end of the harvest season were counted after which the leaf areas were measured using a Li-3100C area meter. Once the leaves were counted, wet/fresh weight matter (FM) of the entire plant in the pot and after $24 \mathrm{~h}$ in pure water at $4^{\circ} \mathrm{C}$, its saturated total weight (TM), and the leaf water contents were determined and converted to dry weight matter (DM) at $65^{\circ} \mathrm{C}$ for $72 \mathrm{~h}$ using Eq. (2) (Bacelar et al., 2006). The remaining biomass parts of the plant other than the leaves were weighed after drying for $24 \mathrm{~h}$ in a drying oven at $70^{\circ} \mathrm{C}$ (Önal, 1991).

$L W C=\frac{(\mathrm{FM}-\mathrm{DM})}{(\mathrm{TM}-\mathrm{DM})} \times 100$

where LWC: leaf water holding capacity (leaf water content, \%), FM: fresh leaf biomass (g), DM: dry leaf biomass (g), TM: turgid leaf biomass $(\mathrm{g})$.

\subsection{Harvest period operations}

Fruits that reached harvest maturity were harvested in three periods (at about one-week interval: 24 March, 31 March, and 7 April). During the harvest, fruits in each replication were both counted and weighted. The data obtained were subjected to analysis of variance (ANOVA) and Duncan comparison tests at a significance level $(p<0.05)$ using SPSS 18.0 (Bek and Efe, 1988).

\subsection{Crop water use}

Plant water consumption was determined weighing the pots in the period between two irrigations from three pots in each application. Before the irrigation treatment, the three control pots were weighed and irrigated at the intervals until water came from underneath the pot.

The volume of water given in each application was measured with the help of a specific beaker. After about a week, the same pots were weighed again to determine the amount of water consumed and crop water use in a week. To offset plant weights in the computation of irrigation requirements, the additional three pots were disintegrated in every 15 days for their measurements in each treatment.

\subsection{Statistical analysis}

Pearson's correlation matrix was performed to detect the strength and direction of linear relationships between the measured variables. The best-fit simple linear regression and non-linear models were chosen using the Bayesian Information Criterion (BIC).

Bayesian Information Criterion aims to balance the trade-off between the goodness-of-fit and parsimony by penalizing model complexity in the selection of the best model from among a set of alternative models. 


\section{Results and Discussion}

\subsection{Irrigation and crop water use}

Water use increased with the increasing irrigation water amount. The highest and lowest seasonal water consumption belonged to $I_{100}$ $(5.82 \mathrm{~L})$ and $\mathrm{I}_{33}(1.89 \mathrm{~L})$, respectively (Figure 1$)$. Compared to $\mathrm{I}_{100}$, water consumption dropped by $54 \%$ with $I_{33}$ and $31 \%$ with $I_{66}$. During the irrigation treatments, the water amount used ranged from 0.23 to $1.20 \mathrm{~L}$. Strawberry has a shallow root system and a large leaf area with a high water requirement (Treder et al., 2009). Islam et al. (2016) determined the irrigation water requirement in three strawberry varieties as $85.25,49.22$ and $49 \mathrm{~mm}$ under the zero evaporation conditions and 351.45 , 324.42 and $338 \mathrm{~mm}$ in field conditions when FAO's crop coefficients $(\mathrm{Kc}$, the ratio of crop-specific and reference crop ET) were used. The water requirement of strawberry varied between 300 and $787 \mathrm{~mm}$ under a wide range of climatic conditions (Serrano et al., 1992; Trout and Gartung, 2004; Hanson and Bendixen, 2004; Strand, 2008).

During the growing period, the crop water use value initially increased and then decreased. Daily maximum water consumption was measured as $1.09 \mathrm{~L}$ for $\mathrm{I}_{100}$ at the beginning of the flowering period. Daily minimum water consumption was measured as $0.12 \mathrm{~L}$ for $\mathrm{I}_{33}$ near the harvest period. Crop water use decreased significantly due to the drought stress. Water consumption was previously reported to vary according to soil, climate, and cultivars. For example, crop water use varied between 430 and $453 \mathrm{~mm}$ with Sabrina cultivar and was estimated at $352 \mathrm{~mm}$ with Antilla cultivar based on lysimeters (Lozano et al., 2016). Maximum water consumption was found as $368 \mathrm{~mm}$ under$0.04 \mathrm{MPa}$ (yield: $28.2 \mathrm{tha}^{-1}$ ) by Giovanardi and Testolin (1984) and as $566 \mathrm{~mm}$ under $-0.01 \mathrm{MPa}$ by
Serrano et al. (1992). They found that as the soil water content decreased, the water lost by transpiration decreased, while the water consumption amount at $-0.03,-0.05$ and $-0.07 \mathrm{MPa}$ was 424,299 and $313 \mathrm{~mm}$, respectively.

The drought stress reduced the amount of fruits, and the fruit weight $(p<0.01)$. According to the three harvests made, the fruit weight and number were higher in the second harvest, while yields were determined as 80, 229 and $400 \mathrm{~g} \mathrm{pot}^{-1}$ with $\mathrm{I}_{33}, \mathrm{I}_{66}$ and $\mathrm{I}_{100}$, respectively. The total fruit weights ranged from 63 to $95 \mathrm{~g} \mathrm{pot}^{-1}$ with $\mathrm{I}_{33}, 195$ to $261 \mathrm{~g} \mathrm{pot}^{-1}$ with $\mathrm{I}_{66}$, and 329 to $538 \mathrm{~g} \mathrm{pot}^{-1}$ with $\mathrm{I}_{100}$. The drought stress also caused similar effects on the number of fruits. The average, (lowest and highest) fruit weights were 30.25 (25-38), 36.50 (34-42) and 41.25 (38-44) with $I_{33}, I_{66}$ and $I_{100}$, respectively. Drought stress decreased fruit yield due to the lower fruit number and size (El-Farhan and Pritts, 1997; Grant et al., 2010; Serrano et al., 1992). The fruit yield was reported to decline by about $80 \%$, while the number of fruits decreased by more than $30 \%$ (El-Farhan and Pritts, 1997). In our study, the decreases by $43 \%$ with $I_{66}$ and by $80 \%$ with $I_{33}$ were observed. Similarly, the number of fruits declined by $12 \%$ with $I_{66}$, and by $19 \%$ with $I_{33}$.

Relative to $\mathrm{I}_{100}$, the $\mathrm{FM}$ value decreased by $47 \%$ and $18 \%$, while the DM value decreased $44 \%$ and $14 \%$ with $I_{33}$ and $I_{66}$. The lack of moisture in the root zone significantly reduced LWC for each sampling during the harvest period. When the soil water content in the root area was insufficient, water loss through transpiration reduced the water amount in the tissues (Klamkowski and Treder, 2008). This response was also observed in many other plant species (Blanke and Cooke, 2004; Lawlor and Cornic, 2002). In our study, LWC was 60, 44.87 and $17.22 \%$ in the stress-free, moderate and severe drought stress levels, respectively. Ghaderi and Siosemardeh (2011) stated that the irrigation done

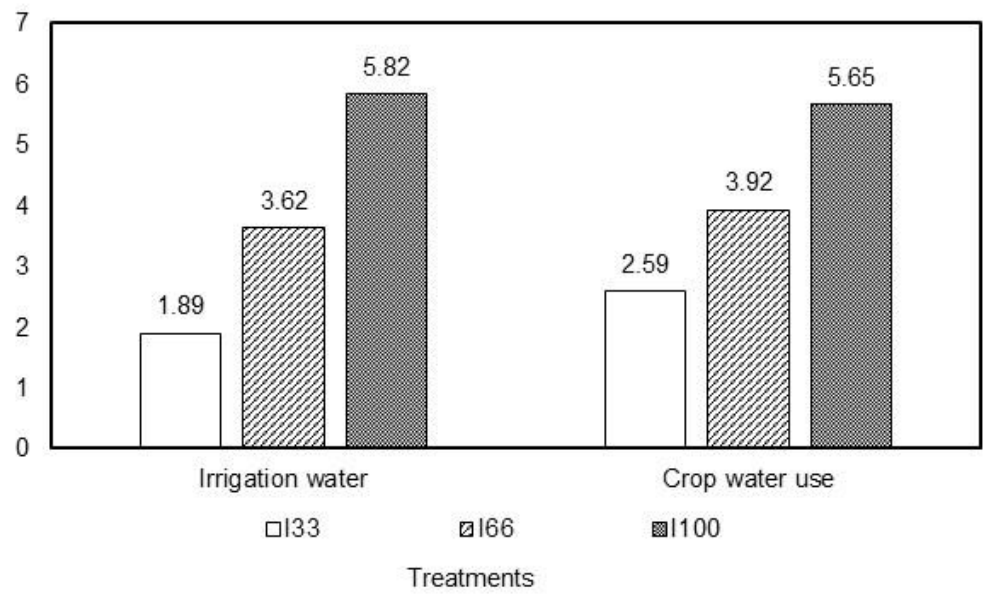

Figure 1. Amount of applied irrigation water and measured crop water use in the study $\left(\mathrm{L} \mathrm{pot}^{-1}\right)$ 
with $50 \%\left(\mathrm{I}_{1}\right)$ and $25 \%\left(\mathrm{I}_{2}\right)$ of the available water capacity decreased LWC by $7 \%$ in $\mathrm{I}_{1}$ and $31.5 \%$ in $\mathrm{I}_{2}$ compared to the full irrigation, and one day after the plants were irrigated in full, LWC was recovered by $97 \%$ and $88 \%$ in two varieties due to the intraspecific differences in leaf moisture content, and interactions between genotype and irrigation applications.

Leaf area was on average 379,582 and $894 \mathrm{~cm}^{2}$ (Figure 2), while the number of leaves was 18, 23 and 31 with $I_{33}$, $I_{66}$ and $I_{100}$ (Figure 3), respectively. According to $l_{100}$, the decrease was by $35 \%$ and $58 \%$ in leaf area, and by $26 \%$ and $42 \%$ in the number of leaves with $I_{66}$ and $I_{33}$, respectively. The drought stress level adversely affected the number of leaves rather than the leaf area. This suggests that the increased stress did not prevent the plant from growing its existing leaves, but its new leaf formation. The numbers of runners, crowns and leaves were previously observed to decrease in long and frequent droughts (El-Farhan and Pritts, 1997). Both leaf area and leaf number had the same relationship with the yield according to the regression models in this study. One $\mathrm{cm}^{2}$ increase in the leaf area and one unit increase in the number of leaves caused 23 and $0.6 \mathrm{~g}$ increases in the yield, respectively.

Osmotic regulation, low transpiration rate, and small leaf area are also the important parameters in the selection of drought tolerant strawberry varieties (Grant et al., 2010). In the strawberry plant exposed to water stress, the leaf expansion rate decreased, while the leaf area of the fully watered plants during the season doubled compared to the plants exposed to stress. Leaf expansion started one hour before sunset, and leaf expansion rate peaked for the next five hours. The leaves of the strawberry plant exposed to the mild drought stress $(75 \%$ of the required water) for four months had less than half the leaf area of the fully watered plant. Part of this difference in the leaf area resulted from stress conditions accelerating the aging and death of all leaves, in particular, old leaves. Under the moderate water stress, young leaves had a relatively higher water content, which reduced the death of young leaves (El-Farhan and Pritts, 1997).

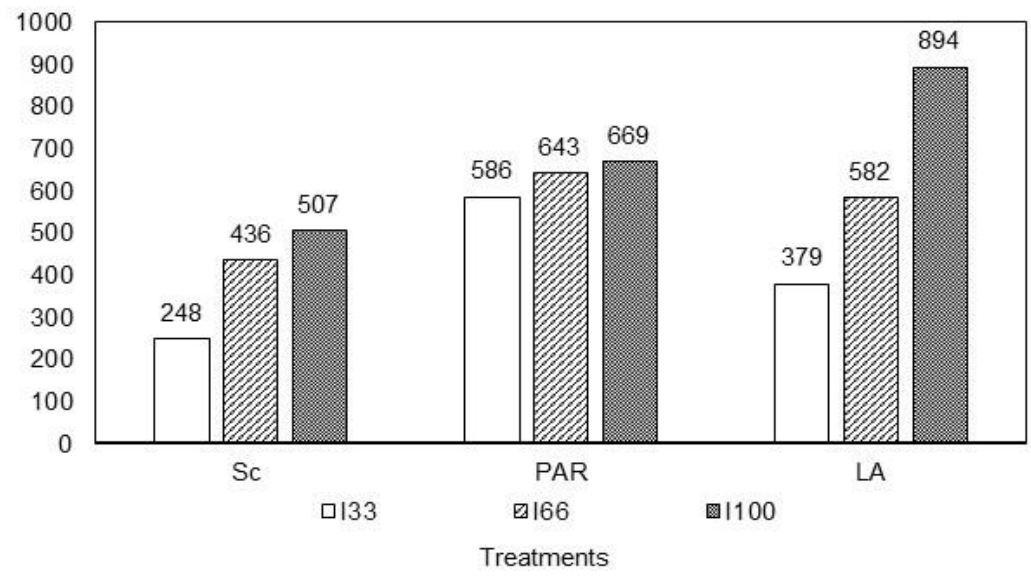

Figure 2. Changes in stomatal conductivity $\left(\mathrm{Sc}, \mathrm{mmol} \mathrm{m} \mathrm{m}^{-1}\right)$, photosynthetically active radiation (PAR, $\left.\mathrm{W} \mathrm{m} \mathrm{m}^{-2}\right)$ and leaf area $\left(\mathrm{LA}, \mathrm{cm}^{2}\right)$ of strawberry leaf in the study

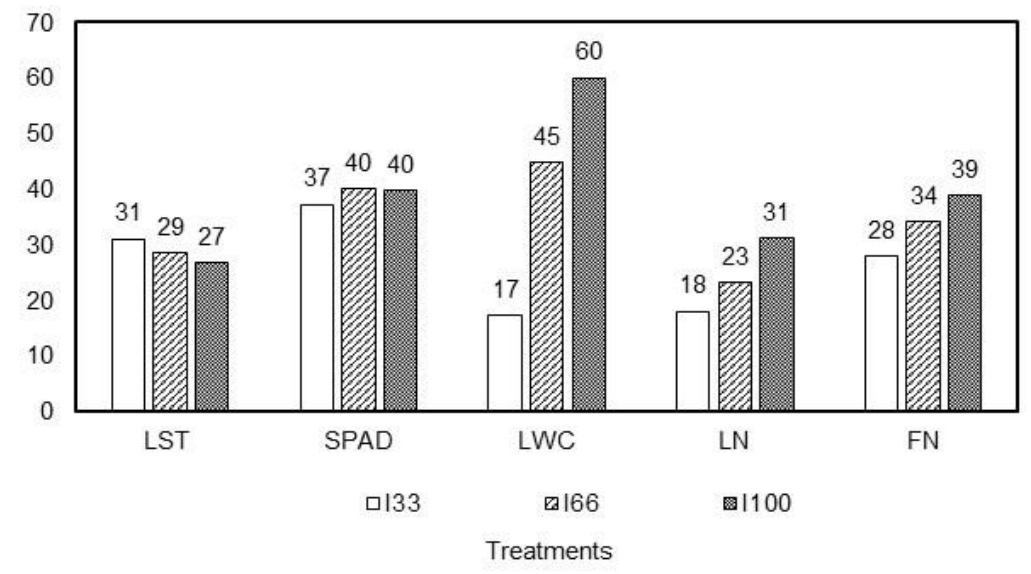

Figure 3. Changes in leaf surface temperature $\left(\mathrm{LST},{ }^{\circ} \mathrm{C}\right)$, total chlorophyll content (SPAD, $\left.\mu \mathrm{mol} \mathrm{m} \mathrm{m}^{-2} \mathrm{~s}^{-1}\right)$, leaf water content (LCW, \%), leaf number (LN) and fruit numbers (FN) of strawberry plant in the study 


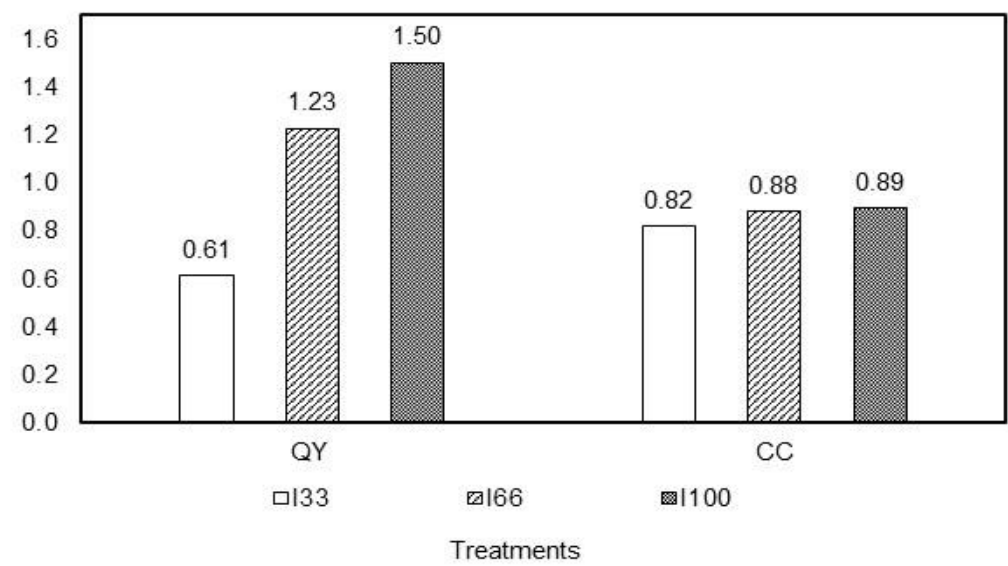

Figure 4. Changes in photosynthetic quantum yield (Qy, \%) and chlorophyll concentration (CC, $\left.\mathrm{mg} \mathrm{g}^{-1}\right)$ of strawberry leaf in the study

The protection of LWC under the drought stress is an important factor in ensuring the drought tolerance of the plants. In preventing the reduction of LWC, the increased osmotic regulation, and the decreased transpiration may increase the drought resistance. Therefore, the stomatal responses of plants can be considered a primary driver to the drought. The stomata are responsible for the gas exchange between the leaf's intercellular space and the atmosphere and sensitive to drought stress (Kerepesi and Galiba, 2000). Stomatal closure protects plants from excessive water loss but also limits the entry of $\mathrm{CO}_{2}$ into the tissue where photosynthesis takes place (Chaves et al., 2003). In our study, Sc decreased linearly as the drought stress severity increased. Sc was estimated at 248 and $507 \mathrm{mmol} \mathrm{m}^{2} \mathrm{~s}^{-1}$ under the severe drought stress and stress-free conditions, respectively (Figure 2). A significant linear increase was found between Sc and yield. According to the development period of the plant, the Sc rate decreased in the aging leaves as it approached the harvest time. The highest time-dependent Sc was measured prior to the fruit formation.

Closing stomata in the drought stress decreased the net $\mathrm{CO}_{2}$ assimilation rate (A) and $\mathrm{ET}$ but increased LST. The LST value of the strawberry leaves was 31,29 and $27^{\circ} \mathrm{C}$ under the severe and moderate drought stress and stress-free conditions, respectively (Figure 3). Ödemiş et al. (2017) pointed out that the increased Sc cooled down the leaf surface as the drought stress decreased and found that each $1^{\circ} \mathrm{C}$ increase in the cotton leaf temperature decreased its yield by $88.7 \mathrm{~kg} \mathrm{da}^{-1}$ in the first year and by $61.2 \mathrm{~kg} \mathrm{da}^{-1}$ in the second year. In this study, each $1^{\circ} \mathrm{C}$ increase caused a decrease by about $75 \mathrm{~g}$.

SPAD and chlorophyll concentrations decreased with the increased drought stress. SPAD values were $37.22,39.93$ and $39.74 \mu \mathrm{mol} \mathrm{m}^{-2} \mathrm{~s}^{-1}$ (Figure 3 ), while chlorophyll concentration was $0.82,0.88$ and $0.89 \mathrm{mg} \mathrm{g}^{-1}$ (Figure 4) under the severe and moderate drought stress and stress-free conditions, respectively. No significant difference was found in chlorophyll concentration between the severe and moderate drought levels. As the drought stress increased for strawberry (Ghaderi and Siosemardeh, 2011), apple (Sircelj et al., 2007) and cotton (Ödemiş et al., 2017), the chlorophyll content decreased. Ghaderi and Siosemardeh (2011) found differences in the chlorophyll content and chlorophyll degradation of two strawberry varieties with prolonged drought stress as well as no recovery with their irrigation.

Photosynthetic quantum yield is a measure of photosynthetic activity expressed as moles of photons absorbed per mole of oxygen released or per mole of $\mathrm{CO}_{2}$ taken (Long et al., 1993). In this study, as drought stress increased, Qy increased linearly. Qy was $0.61,1.23$ and 1.50 under the severe and moderate drought stress and stress-free conditions, respectively (Figure 4). Ödemiş et al. (2017) pointed out that Qy in cotton initially increased and then decreased due to the increased irrigation water amount. El-Farhan and Pritts (1997) estimated the photosynthetic rates as $35 \mathrm{mg}$ $\mathrm{CO}_{2} \mathrm{dm}^{-2} \mathrm{~h}^{-1}$ and $16 \mathrm{mg} \mathrm{CO}_{2} \mathrm{dm}^{-2} \mathrm{~h}^{-1}$ in stress-free and stressful conditions, respectively.

The decreased leaf area and number as a result of the increased drought stress severity reduced PAR that strawberry plants could absorb in photosynthesis. PAR was $586 \mathrm{~W} \mathrm{~m}^{-2}$ with $\mathrm{I}_{33}$ and $669 \mathrm{~W} \mathrm{~m}^{-2}$ with $\mathrm{I}_{100}$ (Figure 2). Many studies showed that yield had a positive relationship with light use efficiency (Whitfield and Smith, 1989; Chen et al., 2003; Li et al., 2008). Our results were consistent with the study by Plénet et al. (2000) that the ratio of PAR absorbed by the canopy depended on leaf area index (LAl), and canopy geometry.

\subsection{Relationships of water use efficiency and light use efficiency with other variables}

Linear or quadratic relationships were obtained between irrigation water, crop water use, and yield (Table 1). The increased irrigation water amount 
and crop water use linearly increased yield, fruit number, leaf area, and leaf number. The FM and DM weights and LWC had polynomial relationships with the irrigation water amount and crop water use. The irrigation water and crop water use affected Sc, SPAD, and Qy but chlorophyll concentration. LST decreased with the increased irrigation water and crop water use. PAR did not respond significantly to the increased irrigation water and crop water use (Table 1). The linear relationship between LST and leaf number was found, while the second-order relationships between all the other variables were obtained.
Pearson's correlation matrix analysis showed that water use efficiency (WUE = fruit weight/ crop water use) were positively correlated with $Q y$ and PAR at $p<0.001$ and Sc and LWC at $p<0.05$ (Figure 5). Light use efficiency (LUE $=$ fruit weight/PAR) was linearly associated with crop water use and irrigation level (IL, $\left.I_{33}>I_{66}->I_{100}\right)$ at $\mathrm{p}<0.05$ (Figure 6). Not only did multicollinearity exist among Sc, Qy, PAR, and LWC but also between crop water use and IL. Hence, the nonlinear models were best fit to WUE and LUE as a function of the individual predictors according to the smallest BIC values (Table 2).

Table 1. Relationships of measured variables with irrigation water and evapotranspiration $(n=3)$

\begin{tabular}{|c|c|c|c|c|}
\hline Response & Irrigation water & $r^{2}$ & Evapotranspiration & $r^{2}$ \\
\hline Yield (g) & $81.124 x-69.888$ & $0.99^{* *}$ & $104.12 x-185.54$ & $0.99^{* *}$ \\
\hline Fruit number & $2.7098 x+23.349$ & $0.98^{* *}$ & $3.4755 x+19.496$ & $0.97^{\star *}$ \\
\hline Leaf area $\left(\mathrm{cm}^{2}\right)$ & $131.43 x+122.04$ & $1^{\star *}$ & $168.78 x-65.69$ & $1^{* *}$ \\
\hline Leaf number & $3.38 x+11.39$ & $0.99^{* *}$ & $4.34 x+6.55$ & $0.99^{* *}$ \\
\hline Dry weight $(\mathrm{g})$ & $-0.13 x^{2}+1.50 x+0.31$ & $1^{* *}$ & $-0.21 x^{2}+2.45 x-2.19$ & $1^{* *}$ \\
\hline Fresh weight $(\mathrm{g})$ & $-0.12 x^{2}+1.62 x+0.39$ & $1^{* *}$ & $-0.21 x^{2}+2.58 x-2.29$ & $1^{* *}$ \\
\hline Leaf water con & $-4.31 x^{2}+39.75 x-42.49$ & $1^{* *}$ & $-7.19 x^{2}+67.63 x-109.68$ & $1^{* *}$ \\
\hline Stomatal conductan & $-46.36 x^{2}+405.42 x-352.96$ & $1^{* *}$ & $-77.14 x^{2}+697.27 x-1040.8$ & $1^{* \star}$ \\
\hline Total chlorophyll content $\left(\mu \mathrm{mol} \mathrm{m} \mathrm{m}^{-2} \mathrm{~s}^{-1}\right)$ & $-0.26 x^{2}+1.34 x+38.34$ & $1^{* *}$ & $-0.43 x^{2}+2.65 x+35.95$ & $1^{* \star}$ \\
\hline Chlorophyll concentration $\left(\mathrm{mg} \mathrm{g}^{-1}\right)$ & $0.0053 x+0.84$ & $0.07 \mathrm{~ns}$ & $0.0069 x+0.83$ & $0.07 \mathrm{~ns}$ \\
\hline Leaf surface temperature $\left({ }^{\circ} \mathrm{C}\right)$ & $-1.05 x+32.78$ & $0.97^{* *}$ & $-1.35 x+34.28$ & $0.96^{* *}$ \\
\hline Photosynthetic quantum yield (\%) & $-0.059 x^{2}+0.68 x-0.47$ & $1^{* *}$ & $-0.099 x^{2}+1.11 x-1.60$ & $1^{* *}$ \\
\hline Photosynthetically active radiation $\left(\mathrm{W} \mathrm{m}^{-2}\right)$ & $8.045 x+602.26$ & $0.14 \mathrm{~ns}$ & $10.49 x+590.12$ & $0.14 \mathrm{~ns}$ \\
\hline
\end{tabular}

ns and ${ }^{* *}$, not significant and significant $p<0.01$, respectively

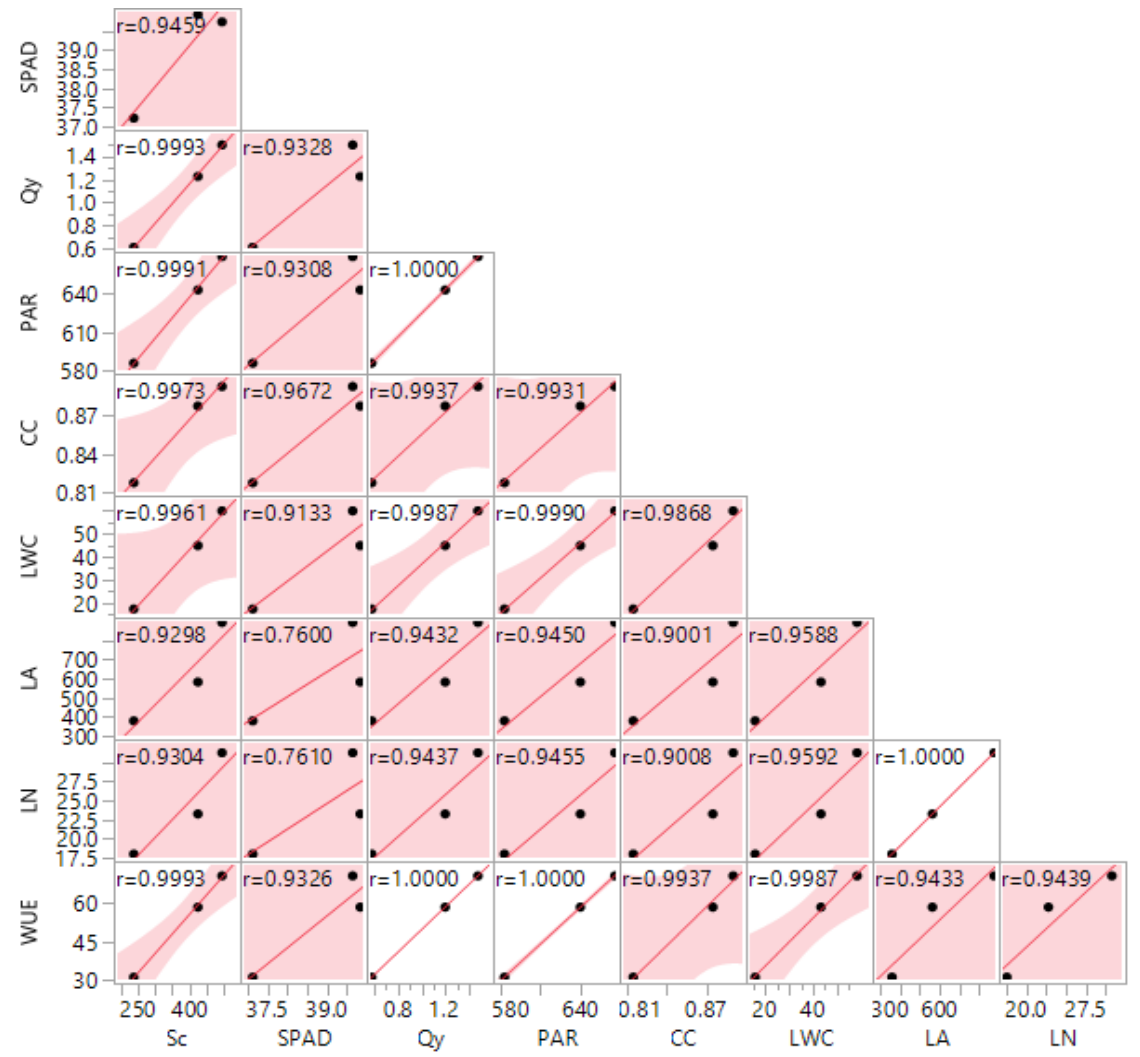

Figure 5. Pearson's correlation matrix of WUE and LN, LA, LWC, CC PAR, Qy, SPAD measured in the drought treatments (WUE: Water use efficiency, LUE: Light use efficiency, LN: Leaf number, LA: Leaf area, LWC: Leaf water content, CC: Chlorophyll concentration, PAR: Photosynthetically active radiation, Qy: Photosynthetic quantum yield, SPAD: Total chlorophyll content, Sc: Stomatal conductance) 


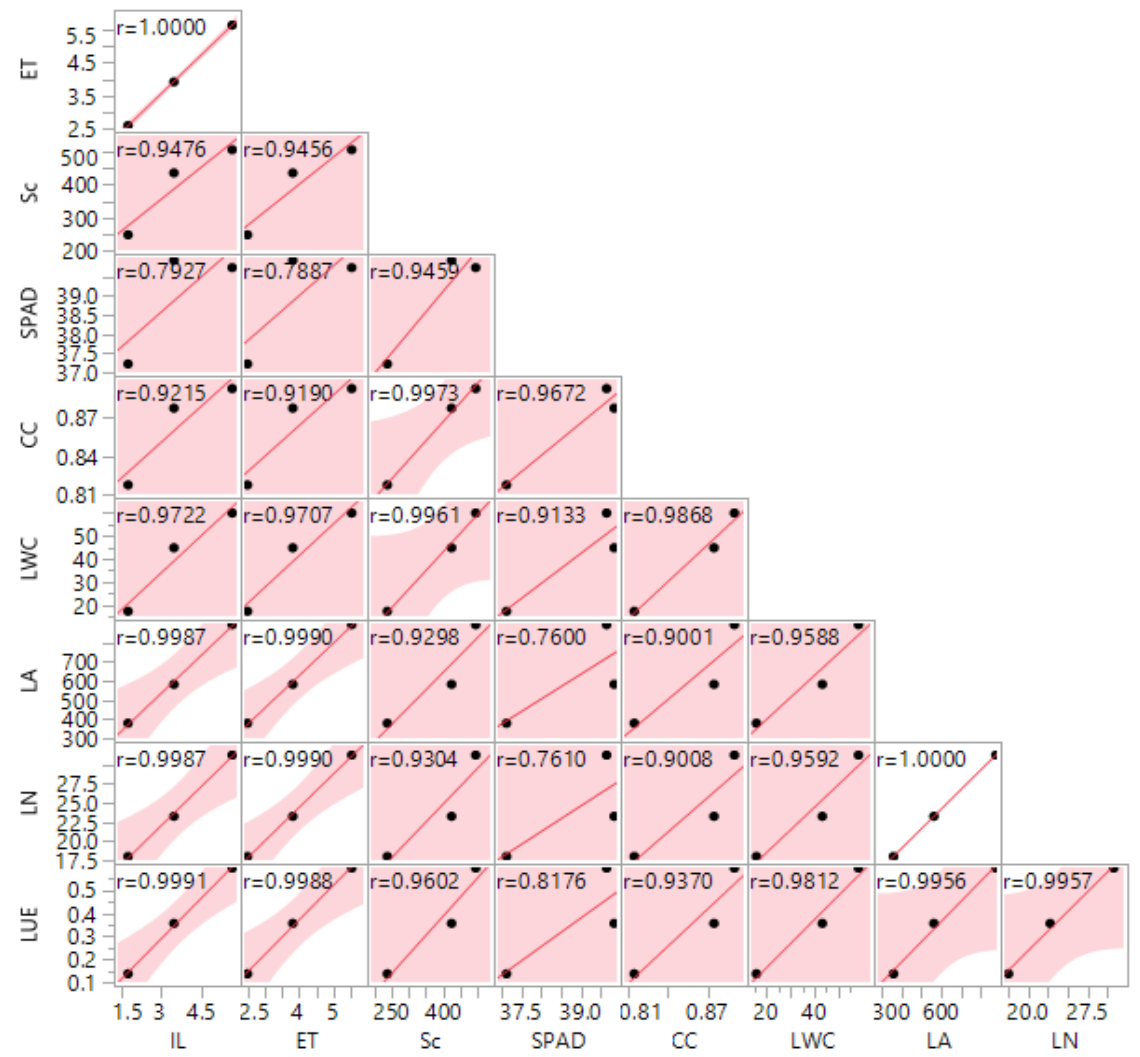

Figure 6. Pearson's correlation matrix of LUE and LN, LA, LWC, CC, SPAD, Sc, ET measured in the drought treatments (LUE: Light use efficiency, LN: Leaf number, LA: Leaf area, LWC: Leaf water content, CC: Chlorophyll concentration, SPAD: Total chlorophyll content, Sc: Stomatal conductance, ET: Crop water use, IL: Irrigation level)

Table 2. The best-fit non-linear models of water use efficiency (WUE = fruit weight/ET) and light use efficiency (LUE = fruit weight/PAR) as a function of the best individual predictors based on the Pearson's correlation matrix analysis $\left(r^{2} \approx 1\right)$

\begin{tabular}{|c|c|c|c|c|c|}
\hline Response & Predictor & Parameter & Estimate & Prediction model & $\mathrm{BIC}$ \\
\hline \multirow{12}{*}{ WUE } & \multirow{3}{*}{ LWC } & $a=$ growth rate & 0.0459 & \multirow{3}{*}{$\frac{c}{(1+\exp (-a *(L W C-b)))}$} & \multirow{3}{*}{-162.1} \\
\hline & & $b=$ inflection point & 31.0096 & & \\
\hline & & $c=$ asymptote & 89.4496 & & \\
\hline & \multirow{3}{*}{ PAR } & $a=$ asymptote & 89.3603 & \multirow{3}{*}{$a *\left(1-\exp \left(-\left(\left(\frac{P A R}{b}\right)^{c}\right)\right)\right)$} & \multirow{3}{*}{-179.1} \\
\hline & & $b=$ inflection point & 639.0374 & & \\
\hline & & $c=$ growth rate & 9.7769 & & \\
\hline & \multirow{3}{*}{ Qy } & $a=$ area under curve & -141.8424 & \multirow{3}{*}{$\left(\frac{(a * b * c)}{c-b}\right) *(\exp (-b * Q y)-\exp (-c * Q y))$} & \multirow{3}{*}{-152.6} \\
\hline & & $b=$ elimination rate & -0.4379 & & \\
\hline & & $c=$ absorption rate & 0.9214 & & \\
\hline & \multirow{3}{*}{ Sc } & $a=$ asymptote & -64.2371 & \multirow{3}{*}{$a *(1-b * \exp (-c * S c))$} & \multirow{3}{*}{-141.6} \\
\hline & & $b=$ scale & 1.0630 & & \\
\hline & & $c=$ growth rate & -0.0013 & & \\
\hline \multirow{6}{*}{ LUE } & \multirow{3}{*}{ ET } & $a=$ intercept & -0.3755 & \multirow{3}{*}{$a+b * E T+c * E T^{2}$} & \multirow{3}{*}{-179.3} \\
\hline & & $b=$ slope & 0.2197 & & \\
\hline & & $c=$ quadratic & -0.0084 & & \\
\hline & \multirow{3}{*}{ IL } & $a=$ growth rate & 0.8507 & & \multirow{3}{*}{-206.6} \\
\hline & & $b=$ inflection point & 3.5092 & \multirow{2}{*}{$\frac{c}{(1+\exp (-a *(I L-b)))}$} & \\
\hline & & $c=$ asymptote & 0.6811 & & \\
\hline
\end{tabular}

WUE: Water use efficiency, LUE: Light use efficiency, LWC: Leaf water content, PAR: Photosynthetically active radiation, Qy: Photosynthetic quantum yield, Sc: Stomatal conductance, ET: Crop water use, IL: Irrigation level 


\section{Conclusion}

Our results showed that the cultivar of 'Camarosa' was drought sensitive related to literature in terms of both physiological and yield parameters. Farmers in semi-arid regions should adopt drought-tolerant varieties, varieties with the highest WUE, an appropriate irrigation schedule, or the best management practices that enhance WUE, based on our results.

\section{References}

Arnon, D.I. (1949). Cooper enzymes in isolated chloroplasts. Polypenoloxidase in Beta vulgaris plant physiology, 24:1-5.

Bacelar, E., Santos, D., Moutinhopereira, J., Goncalves, B., Ferreira, H., \& Correia, C. (2006). Immediate responses and adaptative strategies of three olive cultivars under contrasting water availability regimes: Changes on structure and chemical composition of foliage and oxidative damage. Plant Science, 170:596-605.

Bek, Y., \& Efe, E. (1988). Araştırma ve Deneme Medotları I. Ç.Ü.Ziraat Fakültesi, Ders Kitabı: No:71, 395 s (in Turkish).

Blanke, M.M., \& Cooke, D.T. (2004). Effect of flooding and drought on stomatal activity, transpiration, photosynthesis, water potential and water channel activity in strawberry stolons and leaves. Plant Gowth Regulations, 42:153-160.

Chaves, M.M., Maroco, J.P., \& Pereira, J.S. (2003). Understanding plant responses to drought - from genes to the whole plant. Functional Plant Biology, 30:239-264.

Chen, Y.H., Yu, S.L., \& Yu, Z.W. (2003): Relationship between amount or distribution of PAR interception and grain output of wheat communities. Acta Agronomica Sinica, 29:730-734.

El-Farhan, A.H., \& Pritts, M.P. (1997). Water requirements and water stress in strawberry. Advance in Strawberry Research, 16:5-12.

Flexas, J., Bota, J., Cifre, J., Escalona, M.J., Galmes, J., Gulias, J., Lefi, E.K., Martinez-Canellas, S.F., Moreno, M.T., Ribas-Carbo, M., Riera, D., Sampol, B., \& Medrano, H. (2004). Understanding downregulation of photosynthesis under water stress: future prospects and searching for physiology tools for irrigation management. Annals of Applied Biology, 144:273-283.

Jackson, P., Rubertson, M., Cupper, M., \& Hammer, G. (1996). The role of physiological understanding in plant breeding from breeding perspective. Field Crops Research, 49:11-37.

Jones, H.G. (1999). Use of thermography for quantitative studies of spatial and temporal variation of stomatal conductance over leaf surfaces. Plant Cell Environment, 22:1043-1055.

Ghaderi, N., \& Siosemardeh, A. (2011). Response to drought stress of two strawberry cultivars (cv. Kurdistan and Selva). Horticulture, Environment, and Biotechnology, 52:6-12.

Giovanardi, R., \& Testolin, R. (1984) Evapotranspiration et response productive du fraisier (Fragaria $x$ ananassa Dutch.) en fonction du regime hydrique du sol. In: Perrier A, Riou C (eds) Les besoins en eau des cultures. INRA, Versailles, p.305.
Grant, O.M., Johnson, A.W., Davies, M.J., James, C.M., \& Simpson, D.W. (2010). Physiological and morphological diversity cultivated strawberry (Fragaria $\times$ ananasa) in response to water deficit. Environmental and Experimental Botany, 68:264-272.

Islam, H., Haq, E., Paul, P.P., Paul, A., \& Hoque, Z. (2016). Water requirement analysis of three strawberry cultivars by using bucket-type lysimeter and its comparative study. Asian Journal of Medical and Biological Research, 2:672-677.

Hanson, B., \& Bendixen, W. (2004). Drip irrigation evaluated in Santa Maria Valley strawberries. California Agriculture, 58:48-53.

Kerepesi, I., \& Galiba, G. (2000). Osmotic and salt stressinduced alteration in soluble carbohydrate content in wheat seedlings. Crop Science, 40:482-487.

Klamkowski, K., \& Treder, W. (2008). Response to drought stress of three strawberry cultivars grown under greenhouse conditions. Journal of Fruit and Ornamental Plant Research, 16:79-188.

Lawlor, D.W., \& Cornic, G. (2002). Photosynthetic carbon assimilation and associated metabolism in relation to water deficits in higher plants. Plant, Cell \& Environment, 25:275-294.

Li, Q.Q., Chen, Y.H., Liu, M.Y., Zhou, X.B., Yu, S.L., \& Dong B.D. (2008): Effects of irrigation and planting patterns on radiation use efficiency and yield of winter wheat in North China. Agricultural Water Management, 95:469-476.

Lichtenhaler, H.K., \& Welburn, A.R. (1983). Determinations of total carotenoids and chlorophylls $a, b$, and extract in different solvents. Biochemical Society Transactions, 11:591-592.

Long, S.P., Postl, W.F., \& Bolhár Nordenkampf, H.R. (1993) Quantum yields for uptake of carbon dioxide in C3 vascular plants of contrasting habitats and taxonomic groupings. Planta, 189:226-234.

Lozano, D., Ruiz, N., \& Gavilán, P. (2016). Consumptive water use and irrigation performance of strawberries. Agricultural Water Management, 169:44-51.

Mansfield, T., \& Davies, W. (1981). Stomata and stomatal mechanisms. in: Paleg Lg, Aspinall D (Eds) The physiology and biochemistry of drought resistance in plants. Academic Press, New York, p: 315-346.

Mittler, R., Merquiol, E., Hallak-Herr, E., Rachmilevitch, S., Kaplan, A., \& Cohen, M. (2001). Living under 'dormant' canopy: a molecular acclimation mechanism of desert plant Retama raetam. Plant Journal, 25:407-416.

Ödemiş, B., Akışcan, Y., Akgöl, B., \& Can, D. (2017). Kısıtlı su koşullarında yapraktan uygulanan kükürt dozlarının pamuk bitkisinin kuraklık toleransına etkileri. TUBITAK, Proje No: 2140254 (in Turkish).

Önal, K. (1991). Meristem kültürü yöntemi ile üretmenin bazı çilek çesitlerinin vegatatif ve generatif özelliklerine etkileri üzerinde araştırmalar. $\mathrm{PhD}$ Thesis, Ege University, Izmir, Turkey (in Turkish).

Passioura, J., Condon, A., \& Richards, R. (1993). Water deficits, the development of leaf area and crop productivity. In Smith Jac, Griffiths H (Eds) Water Deficits. Plant Responses from Cell to Community. Bıos Scientific Publishers, Oxford, 253-264.

Plenet, D., Mollier, A., \& Pellerin, S. (2000): Growth analysis of maize field crops under phosphorus deficiency. II. Radiation-use efficiency, biomass accumulation and yield components. Plant Soil, 224:259-272. 
Richards, R.A. (2006). Physiological traits used in the breeding of new cultivars for water-scarce environments. Agricultural Water Management, 80:197-211.

Serrano, L., Xavier, C., Robert, S., Oriol, M., \& Josep, P. (1992). Effects of irrigation regimes on the yield and water use of strawberry. Irrigation Science, 13:45-48.

Sircelj, H., Tausz, M., Gill, D., \& Batic, F. (2007). Detecting different levels of drought stress in apple (Malus domestica Borkh.) with selected biochemical and physiological parameters. Scientia Horticulturae, 113:362-369.

Slafer, G.A., Araus, J.L., Royo, C., \& Del Moral, L.F.G. (2005). Promising ecophysiological traits for genetic improvement of cereal yields in mediterranean environments. Annals of Applied Biology, 146:61-70.

Strand, L.L. (2008). Integrated pest management for strawberries (Vol. 3351), UCANR Publications, California, USA.
Treder, W., Klamkowski, K., Krzewińska, D., \& TryngielGać, A. (2009). The latest trends in irrigation technology - Research related to irrigation of fruit crops conducted at the Research Institute of Pomology and Floriculture in Skierniewice. Infrastruktura i Ekologia Terenów Wiejskich, 6:95107.

Trout, T.J., \& Gartung, J. (2004). Irrigation water requirements of strawberries. Proceedings of California Plant and Soil Conference, California, USA. Ed.by: California Chapter of the American Society of Agronomy, pp. 54-59.

Walter, A., \& Shurr, U. (2005). Dynamics of leaf and root growth: endogenous control versus environmental impact. Annals of Botany, 95:891-900.

Whitfield, D.M., \& Smith, C.J. (1989): Effect of irrigation and nitrogen on growth, light interception and efficiency of light conversion in wheat. Field Crops Research, 20:279-295. 